\title{
Needs Analysis of English for Economic Management at Riau Kepulauan University
}

\author{
Dewi Yana \\ University of Riau Kepulauan (UNRIKA) \\ Batam, Indonesia \\ alifdewi@yahoo.com
}

\begin{abstract}
Needs analysis is a way of gathering information related to the beliefs, attitude, and opinion of the learner or the teacher. It can be used to minimize the gap among teacher, learners, and teaching materials. Needs analysis responds the learners' actual needs, and helps in making change and innovation for course programs. This study aims at identifying and analyzing the students' language needs in learning English as foreign language for Economic Management. This research was a qualitative descriptive research. The respondents were the students and the English lecturers of Economic Management Department of Riau Kepulauan University. Then, questionnaire, and semi structure interview were conducted as the method of collecting the data. The data from findings were displayed, analyzed and interpreted descriptively. The results of the study provide valuable recommendations for lecturers and curriculum developers in designing appropriate English course syllabus and learning materials for Economic Management students.
\end{abstract}

\section{Keywords-Needs Analysis; English for Economic} Management

\section{INTRODUCTION}

English is recognized as International language, and it is considered as a foreign language in Indonesia. It is relevant to the geographic and historical spread of English as Kachru's model that Indonesia belongs to expanding or extending circle (Lauder:2008). It means that English in Indonesia is still not set up as official language of the country. It just taught formally in senior-junior high school and university. As a result most of Indonesian "less-than-adequate knowledge of English" (Lauder: 2008). Nonetheless it is needed for the development of Indonesian country. English is used as an instrument to access global communication, education and global marketplace. Then, in most cases of English language teaching in Indonesia does not build under the analysis of learner's language needs. There was less study to plan a language teaching in the class (Makara:2008).Consequently teachers do not sure what their learner's language needs are. The case is also exist in Universitas Riau Kepulauan (UNRIKA). Here, English is taught in five faculties as a compulsory course. But as the data quoted from online journal system of UNRIKA it was found that only one study of English needs analysis have done entitled A Needs Analysis for English Speaking Syllabus Development.(www.journal .unrika.ac.id). Even though needs analysis is the first step of ideal way to plan language learning. Soghori (2008:2) revealed that several scholars and authors such as Munby, Richterich and Chancerel, Hutchinson and Waters, Berwick, Brindley, Tarone and Yule, Robinson, Johns, West, Allison et al. Seedhouse, Jordan, Dudley-Evans and St. John, Iwai et al. Hamp- Lyons, Finney agreed that needs analysis plays a vital role in the second language or foreign language courses. It because needs analysis make a harmonies relationship among all of the teaching learning components in a language course process.

Designing and carrying out a language course through needs analysis can minimize the gap between teachers and learners. Manalullaili explained that analyzing the learners needs will help the learners learn naturally related to their interest (Manalullaili,2014). Toward need analysis the teacher can gather some information about particular language function. This way help teachers specify the language learning from general purposes to be specific purposes. This way also guides teachers in directing the language teaching learning process match to the real work. It is then will promote The Indonesian Qualification Framework or Kerangka Kualifikasi Nasional Indonesia (KKNI). Eventually, this study was intended to find some information regarding the learners' needs of English language course at Economic Management Program of Riau Kepulauan University.

\section{METHOD}

This research is categorized into a qualitative research. The participants of this study were 5 lecturer and 112 students of Management Program of Economic Faculty Riau Kepulauan University. The data collection instruments were in the form of a short interview guidelines and a questioner sheet In the questionnaire, the learners were asked to answer several questions in relation to their perception of English for Economic Management, their present and future domains of language use, and their preferred learning styles; teacher and learner roles; learners' preference of learning activities and strategies. However, they are also allowed to give other answers related to the questions. The data investigated were presented in the form of graphs and analyzed descriptively.

\section{FINDING AND DISCUSSION}

The results of the needs analysis are presented and discussed thematically. They are as in the figure 1: 
Fig. 1. Students' perception toward the importance of English and the needs of English in future career

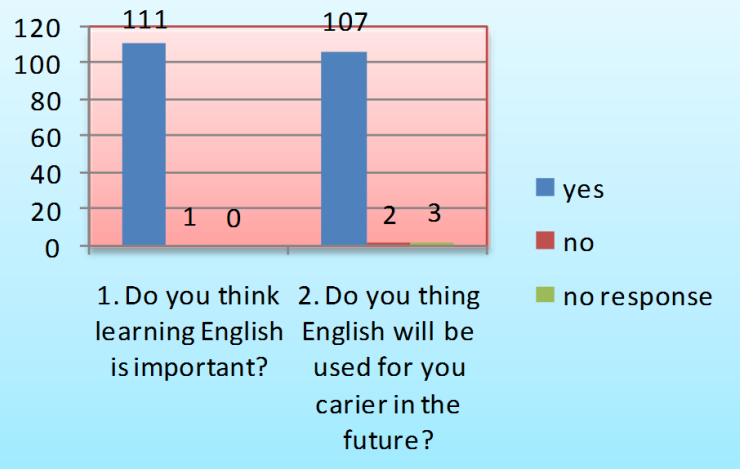

Students were asked to response two questions in term of their perception. For the first question related to the importance of learning English. Almost of the students (111 or 99\%think) clearly response 'yes' and only 1\% think "no". The second question was due to the learners' opinion to the needs of English to support their career in the future. 107 or (95\%) students think that English will be used in the future career and only $2(2 \%)$ of them think English will not be used and $3(3 \%)$ did not give any response. It can be implied that most of the Economic Management students of UNRIKA are understand well about the importance of English as a mean of International language. They are also aware well to their needs in the future where English will gives some advantages to support their career. It can be seen from the figure 2 .

Fig. 2. The present goal of the language use

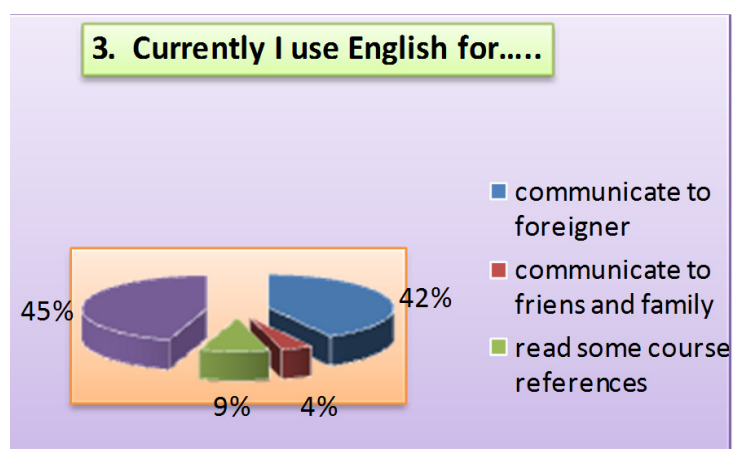

The data of language use can be seen in figure 2 above. It describes that the students were asked to response the goal of language use at present. The $42 \%$ of the students use English to communicate to foreigner, $9 \%$ of them use English to read some course references and only $4 \%$ use English to communicate to friend and family. Then majority of them $(45 \%)$ did not give any response. The data indicated most of the students did not prepare their self with the skill of English. If it is connected to the data in Figure 1, it can be sum up that the students have a good understanding to the importance of English but now majority of them still not do a valuable effort to develop their English competence. It can be seen from the figure 3 .
Fig. 3. The future goal of the language use

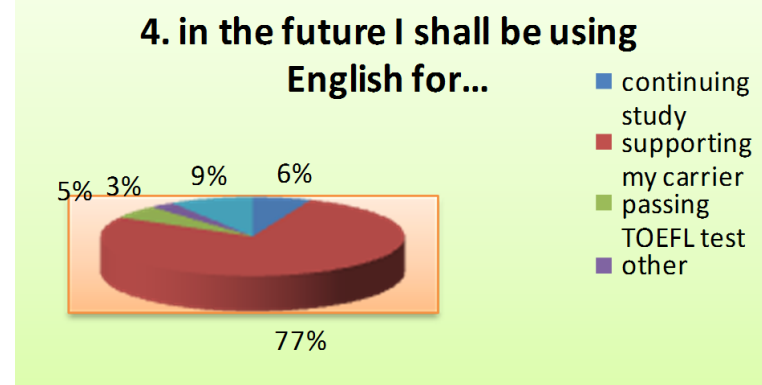

Question number 4 investigated the future goals of language use. Figure 3 shows that most of the student (77\%) will use English to support their career, $6 \%$ of them will use it to continue their study, $5 \%$ will use it as preparation to pass the TOEFL test, $3 \%$ give other response such as for sending email, for teaching their future children, for getting work, for round overseas, and for combination purposes continuing study, supporting career, and passing the TOEFL test, and $9 \%$ of them did not give any response. Therefore, it means that majority of Economic Management students of UNRIKA needs English for their career in the future. It can be seen from the figure 4 .

Fig. 4. The situational of the language use

5. When do you use English?

when learning

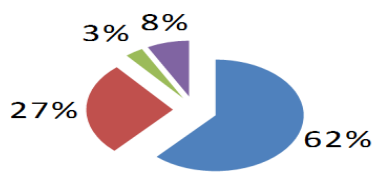

when socializing
when communicating
to family at home
other

Question number 5 was aimed at knowing the situation of language use. Figure 4 above revealed that $62 \%$ of the learners use English when they are learning, 27\% of them use it when they are socializing, $3 \%$ of them use it when they are communicating to family at home and $8 \%$ of them give other reasons such as when it is needed or incidentally. . It can be seen from the figure 5 .

Fig. 5. Learners' believe on the existing of the syllabus to their needs

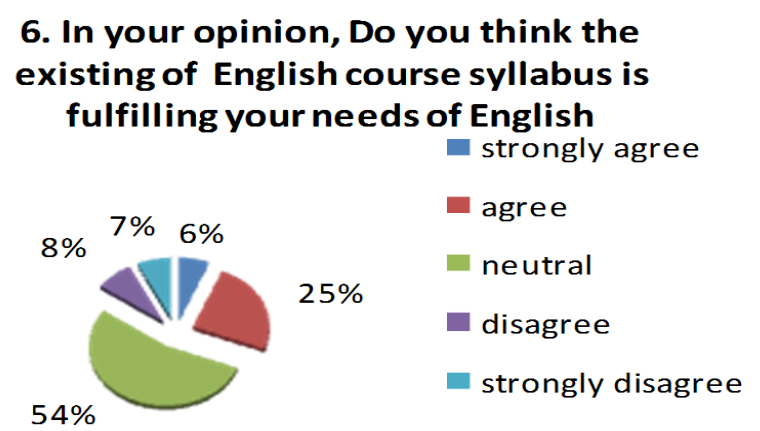


Question number six was intended to find out the learner's believe on the correlation of existing English course syllabus to their language needs. It can be seen in Figure 5 that $54 \%$ of the learners are not sure whether the existing English course syllabus fulfills their learning needs or not, $25 \%$ agree, $8 \%$ disagree, $7 \%$ strongly disagree, only $6 \%$ strongly agree that the English course syllabus meet their needs of English. . It can be seen from the figure 6 .

Fig. 6. Learners' believe to the learning materials they have learnt

\section{Do you think the English learning material you learnt has fulfilling your needs as an economic management students?}

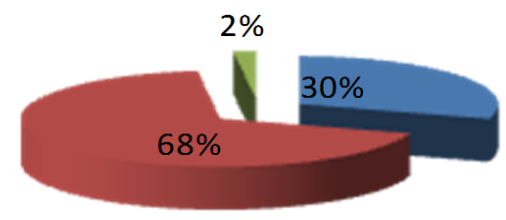

$$
\begin{aligned}
& \text { yes } \\
& \text { not yet } \\
& \text { no at all }
\end{aligned}
$$

Question number seven was about the students' opinion to the existing material whether it suits their needs as Economic Management or not. The result in Figure 6 describes that $68 \%$ of them clearly stated "not yet", $30 \%$ believe "'yes" and $2 \%$ of them believe that the existing materials does not match at all to their language needs as Economic Management Student. . It can be seen from the figure 7.

Fig. 7. Learners' believe to the needs of specific topic for Economic Management

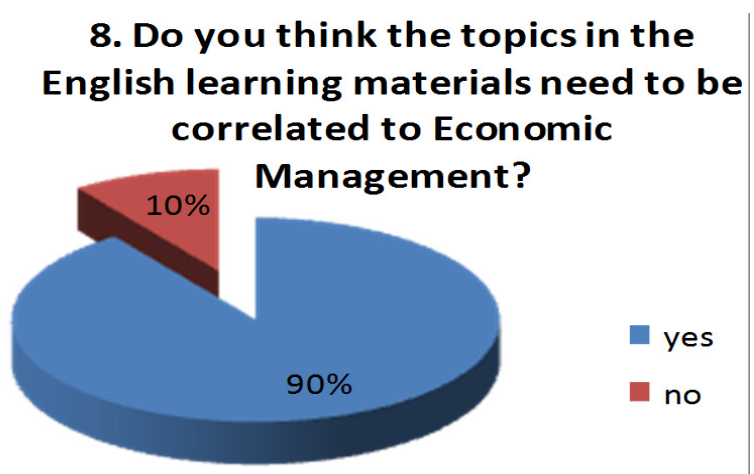

Question number eight was to find out the learners' opinion whether the topics of English learning should be specified for Economic Management or not. Figure 7 shows the data found that $90 \%$ of the learners think the topics in the English learning materials need to be focused to their field, and only $10 \%$ of them think it does not need to be correlated to Economic Management. . It can be seen from the figure 8 .
Fig. 8. Example of a figure caption.

9. Do you think your English skills influence your academic performance?

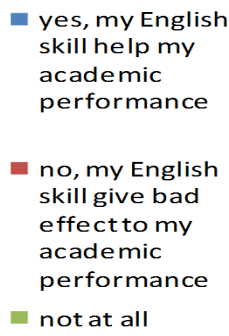
performance

no, my English skill give bad effect to my academic performance

not at all

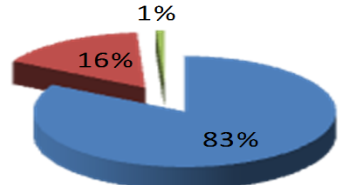

Question number 9 investigated the learners' perspectives whether their English skills influence their academic performance or not. The figure 8 above shows that $83 \%$ of the learners thought the English skill help their academic performance. And $16 \%$ of them thought it was give bad effect to their academic performance. And only $1 \%$ think it was not give effect at all. . It can be seen from the figure 9 .

Fig. 9. Learners' preference to the needs of skill tobe developed

10. which of the following skills do you need more to be developed?

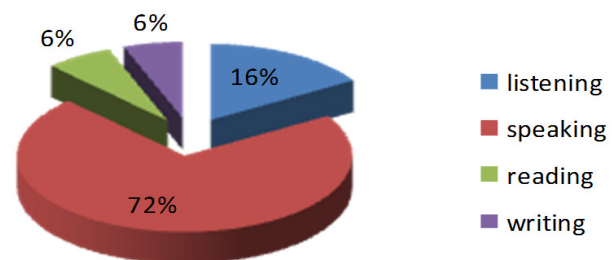

Question number ten is to find out the learners' preference to the more needed skills to be developed. The result shows that $72 \%$ of the learners prefer speaking skill is the most to be developed, in the second skill is listening (16\%), then $6 \%$ for reading skill and also $6 \%$ for writing skill. . It can be seen from the figure 10 .

Fig. 10. Learners' preference of learning activities

\section{How do you prefer to do learning activities in the class?}

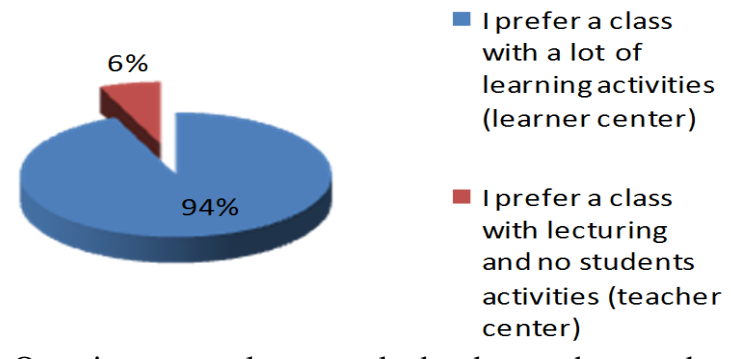

Question no eleven asked about the students' preference of learning activities in the classroom. It can be seen from figure 10 that $94 \%$ of the learners prefer to have a 
class with a lot of activities, and only $6 \%$ of them were like lecturing. . It can be seen from the figure 11 .

\section{Fig. 11. Learners' preference of learning setting}

\section{What kinds of learning setting do you need to do your activities in the class?}

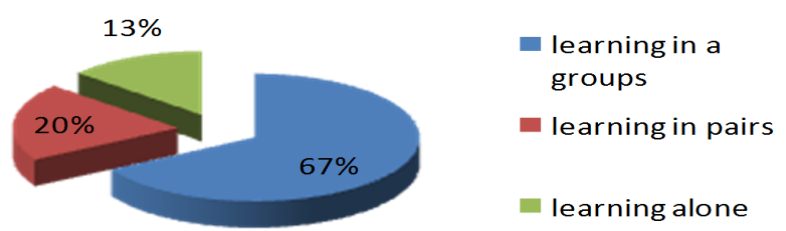

Questions number 12 investigated the student's preference of learning setting they need in the classroom. We can see that the data on figure 11 notes $67 \%$ of the learners prefer to do the activities in grouping; $20 \%$ of them prefer for working in pair and $13 \%$ prefer doing their activities alone. . It can be seen from the figure 12 .

\section{Fig. 12. Learners' preference of the teacher role}

\section{What kinds of teacher role do you prefer in the class?}
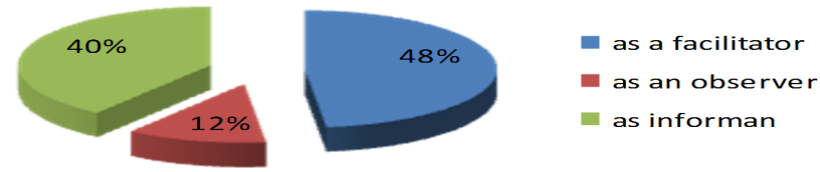

Question number 13 focused to examine the students' preference of teacher's role. The result in figure 12 above describes that $48 \%$ of the students assumed for the role of teacher as a facilitator, $40 \%$ preferred a teacher as an informan, and only $12 \%$ of them preferred teacher role as an observer.

The results provide some information that majority of the students aware to the importance of English as a tool of International language. Currently they felt English was give positive impact to their academic performance. It is noted in Figure 8 that $83 \%$ of the students considered their English skill help them running their academic. They also aware that they need English not only for general purposes such as for build communication with other, but they also have a big understanding that English plays important role in succeeding their career in the future. It was clearly presented in Figure 3 $77 \%$ of the students conscious they will use English to support their career. Since they are concern their study at Economic management, it can be considered that their career will be due to this field. It was strengthen by their opinion in responding the question "do you think the topics in English learning materials need to be correlated to Economic Management?" The result in Figure 7 revealed $90 \%$ of the students want the topics to be specified related to Economic Management.
Therefore, it cannot be neglected they need English for Specific purposes that is for Economic Management. Unfortunately, the English teaching given in the Economic Management is still not specified yet.

TABLE 1. RESUME OF ENGLISH LECTURERS SHORT INTERVIEW RESULTS OF ENGLISH TEACHING GOAL AT ECONOMIC MANAGEMENT

\begin{tabular}{|c|c|c|c|c|}
\hline \multicolumn{5}{|c|}{ Questions } \\
\hline $\begin{array}{l}\text { Respon- } \\
\text { dents }\end{array}$ & $\begin{array}{l}\text { Have you } \\
\text { ever taugth } \\
\text { English at } \\
\text { Economic } \\
\text { Manageme } \\
\text { nt Program } \\
\text { of } \\
\text { UNRIKA? }\end{array}$ & $\begin{array}{l}\text { How long } \\
\text { you have } \\
\text { been taught } \\
\text { there? }\end{array}$ & $\begin{array}{l}\text { How many } \\
\text { English } \\
\text { coures } \\
\text { provided } \\
\text { there? }\end{array}$ & $\begin{array}{l}\text { What are the } \\
\text { goals of the } \\
\text { courses given? }\end{array}$ \\
\hline $\begin{array}{c}\text { lecturer } \\
1\end{array}$ & yes & $\begin{array}{l}\text { 5 semester } \\
\text { since } 2013\end{array}$ & $\begin{array}{l}2 \text { courses } \\
\text { Bahasa } \\
\text { Inggris I } \\
\text { and Bahasa } \\
\text { Inggris II, } \\
\text { and I ever } \\
\text { taught both } \\
\text { of them }\end{array}$ & $\begin{array}{l}\text { Bahasa Inggris I } \\
\text { for general, } \\
\text { Bahasa Inggris } \\
\text { II for TOEFL } \\
\text { preparation }\end{array}$ \\
\hline $\begin{array}{c}\text { lecturer } \\
2\end{array}$ & yes & $\begin{array}{l}3 \text { semester } \\
\text { since } 2013\end{array}$ & $\begin{array}{l}2 \text { courses, I } \\
\text { taught both } \\
\text { of them }\end{array}$ & $\begin{array}{l}\text { Bahasa Inggris I } \\
\text { for general, } \\
\text { Bahasa Inggris } \\
\text { II for TOEFL } \\
\text { preparation }\end{array}$ \\
\hline $\begin{array}{c}\text { lecturer } \\
3\end{array}$ & yes & $\begin{array}{l}1 \text { semester } \\
\text { since } 2017\end{array}$ & $\begin{array}{l}2 \text { courses, I } \\
\text { taugh } \\
\text { Bahasa } \\
\text { Inggris I }\end{array}$ & $\begin{array}{l}\text { Bahasa Inggris I } \\
\text { for general, } \\
\text { Bahasa Inggris } \\
\text { II for TOEFL } \\
\text { preparation }\end{array}$ \\
\hline $\begin{array}{c}\text { lecturer } \\
4\end{array}$ & yes & $\begin{array}{l}1 \text { semester } \\
\text { since } 2017\end{array}$ & $\begin{array}{l}2 \text { coures, I } \\
\text { taught } \\
\text { Bahasa } \\
\text { Inggris II }\end{array}$ & $\begin{array}{l}\text { Bahasa Inggris I } \\
\text { for general, } \\
\text { Bahasa Inggris } \\
\text { II for TOEFL } \\
\text { preparation }\end{array}$ \\
\hline $\begin{array}{c}\text { lecturer } \\
5\end{array}$ & yes & $\begin{array}{l}1 \text { semester } \\
\text { since } 2017\end{array}$ & $\begin{array}{l}2 \text { coures, I } \\
\text { taught } \\
\text { Bahasa } \\
\text { Inggris II, it } \\
\text { is for } \\
\text { TOEFL }\end{array}$ & $\begin{array}{l}\text { Bahasa Inggris I } \\
\text { for general, } \\
\text { Bahasa Inggris } \\
\text { II for TOEFL } \\
\text { preparation }\end{array}$ \\
\hline
\end{tabular}

The information provided by the lecturers in Table 1 Shows that there are two English courses set at Economic Management Program, namely Bahasa Inggris I and Bahasa Inggris II. Remain their teaching experiences taught there, they said Bahasa Inggris I is designed for general purposes, and Bahasa Inggris II is for TOEFL test preparation. In addition, majority of the students $(54 \%)$ were not sure whether the syllabus was fulfilled their needs as Economic Management or not (Figure 5). Then, it would be acknowledged from Figure 4 that $62 \%$ of the student used English only when they were learning English at the classroom. This condition can be considered as their awareness of the English teaching syllabus given. They intended to focus to the process of learning rather than the syllabus. More over syllabus is the duty of the lecturers, not theirs. Furthermore Figure 6 described that $68 \%$ of the students' believe English learning materials given for them did not fulfilling their needs as Economic Management students. Consequently lecturers have a big responsible to this 
condition. They could not close their eyes of the students' needs in planning a language teaching. The result of this study should be considered for further syllabus development. It should be believed that this way also will relevant to Indonesian Qualification Framework or KKNI.

\section{CONCLUSION AND RECOMMENDATION}

This study has indicated the empirical data regarding the Students' language needs of Economic Management of Riau Kepulauan University. It is offering some major conclusions. Firstly, majority of the Economic Management students are aware to the importance of English as a means of International language and to the advantages of English learning for their future. Secondly, this study found that the students need specific language learning materials and they intended the topic to be regarded to the Economic Management field. But in other side this study also found that the existing language teaching given in this program is settled for general purposes. Eventually, the results found were expected being considered by Economic Management Program to specify the goals of English language course and to develop an appropriate teaching syllabus, to design suitable materials, even to renew the curriculum structure of English course at Economic Management of Riau Kepulauan University.

\section{Acknowledgment}

I thank to the Dean of Teacher Training and Education Faculty (FKIP) UNRIKA for providing information needed in this study.

\section{References}

[1] Boroujeni \& Fard. A Needs Analysis of English for Specific Purposes (ESP) Course For Adoption Of Communicative Language Teaching :( A Case of Iranian First-Year Students of Educational Administration. International Journal of Humanities and Social Science Invention ISSN (Online): 2319 - 7722, ISSN (Print): 2319 - 7714 www.ijhssi.org Volume 2 Issue 6 || June. 2013. PP.35-44

[2] Haque, Nurul. A Brief Study on Need Analysis. Express, an International Journal of Multi Disciplinary Research ISSN: 2348 - 2052 , Vol. 1, Issue 1, January 2014 Available at: www.express-journal.com

[3] Hutchinson, T. \& Waters, A.. English for specific purposes: A learningcentered approach. Cambridge University Press. 1991. Cambridge

[4] Jeclezeweski, Sebastian. Needs Analysis, Course Design and Evaluation of Business English. School of Humanities. Department of English.2016. University of Iceland.

[5] Lauder,Allan. "The Status and Function of English in Indonesia: A review of Key Factors" MAKARA, SOSIAL HUMANIORA, VOL. 12, NO. 1, JULI: 9-20 Universitas Indonesia Depok. 2018. Indonesia.

[6] Manalullaili. Teaching Speaking for Slow Learners. Proceedings of The $3^{\text {rd }}$ UAD TEFL International Conference . "ELT Materials Development in Asia and Beyond: Directions, Issues, and Challenges”. September 1718 September, 2014. Yogyakarta, Indonesia.

[7] Otilia. Needs Analysis In English For Specific Purposes. Annals of the „Constantin Brâncuşi” University of Târgu Jiu, Economy Series, Issue 1, volume II/2015

[8] Pushpanathan, “A Need For Needs Analysis". International Journal of Applied Research \& Studies ISSN 2278 - 9480. 2013. India

[9] Soghori, Haseli.Mehdi. " Introduction to Needs Analysis". English for Specific Purposes world, Issue 4, 2008, www.esp-world.info.
[10] Yana, Dewi. "A Needs Analysis for English Speaking Syllabus Development." ANGLO-SAXON vol 7, No 2016 http://journal.unrika.ac.id 